\title{
Erratum to: Approximation of a kind of new type Bézier operators
}

Mei-Ying Ren ${ }^{1 *}$, Xiao-Ming Zeng ${ }^{2}$ and Wen-Hui Zhang ${ }^{2}$

\section{"Correspondence:} npmeiyingr@163.com ${ }^{1}$ School of Mathematics and Computer Science, Wuyi University, Wuyishan, 354300, China Full list of author information is available at the end of the article
The original version of this published article [1] neglected to include the third co-author to the author list. The complete author list can be found at the top of this article and also below:

Mei-Ying Ren ${ }^{1}$, Xiao-Ming Zeng ${ }^{2}$ and Wen-Hui Zhang ${ }^{2}$

${ }^{1}$ School of Mathematics and Computer Science, Wuyi University, Wuyishan, 354300, China

${ }^{2}$ School of Mathematical Sciences, Xiamen University, Xiamen, 361005, China

\section{Author details}

'School of Mathematics and Computer Science, Wuyi University, Wuyishan, 354300, China. ${ }^{2}$ School of Mathematical Sciences, Xiamen University, Xiamen, 361005, China.

Received: 7 January 2016 Accepted: 7 January 2016 Published online: 15 January 2016

References

1. Ren, MY, Zeng, XM, Zhang, WH: Approximation of a kind of new type Bézier operators. J. Inequal. Appl. 2015, 412 (2015)

\section{Springer}

Submit your manuscript to a SpringerOpen ${ }^{\circ}$ journal and benefit from:

- Convenient online submission

Rigorous peer review

- Immediate publication on acceptance

- Open access: articles freely available online

- High visibility within the field

Retaining the copyright to your article

Submit your next manuscript at $>$ springeropen.com 